\title{
Tattoo-induced systemic sarcoidosis
}

\author{
Hisako Kushima, ${ }^{1,2}$ Yoshiaki Kinoshita, ${ }^{2}$ Hiroshi Ishii 다 , ${ }^{2}$ Masaki Fujita ${ }^{1}$
}

'Department of Respiratory Medicine, Fukuoka University Hospital, Chikushino, Fukuoka, Japan

${ }^{2}$ Department of Respiratory Medicine, Fukuoka University Chikushi Hospital, Chikushino, Fukuoka, Japan

\section{Correspondence to}

Professor Hiroshi Ishii; hishii@fukuoka-u.ac.jp

Accepted 9 July 2020

\section{DESCRIPTION}

A 35-year-old Japanese man was admitted to the Department of Ophthalmology with a 4-month history of abnormal vision and was diagnosed with uveitis. The patient had acquired a tattoo on the bilateral shoulders 6 months before the onset of the eye symptoms. He did not have any significant medical or family history, including sarcoidosis. The ophthalmologist suspected sarcoidosis from the findings of uveitis and consulted with the Department of Respiratory Medicine. His serumACE (23.9 U/L, upper limit of normal; 21.4 $\mathrm{U} / \mathrm{L})$ and soluble interleukin-2 receptor (1410 U/ $\mathrm{mL}$, upper limit of normal; $474 \mathrm{U} / \mathrm{mL}$ ) levels were elevated. Thoracic CT revealed no hilar or mediastinal lymphadenopathy; however, numerous tiny perilymphatic nodules were observed in the lungs that were consistent with the findings of pulmonary sarcoidosis. In addition, the patient noticed nodular lesions within the tattoo (figure 1) around the same time as the manifestation of eye symptoms. The pathological findings

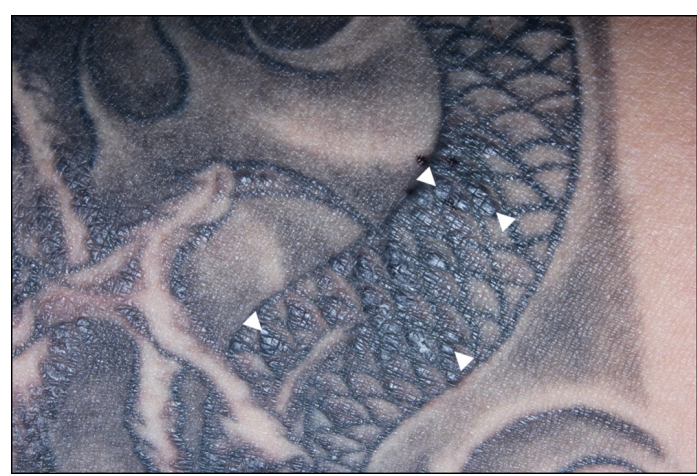

Figure 1 A photograph of the patient's skin, showing multiple small nodules (arrowheads) within the tattoo.

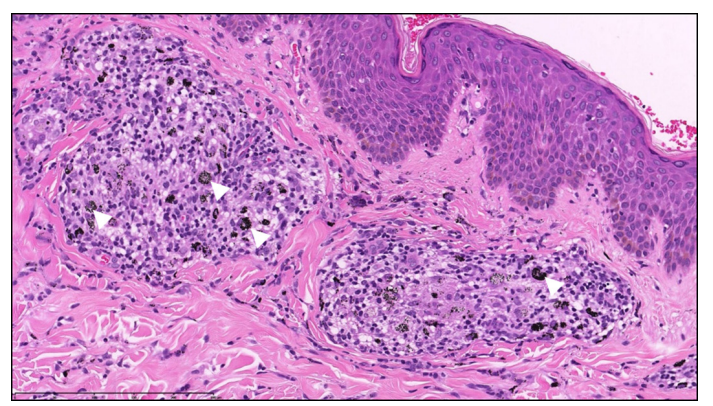

Figure 2 A photomicrograph of a punch biopsy obtained from the papule, showing non-caseating epithelioid cell granulomas with multinucleated giant cells containing numerous black and brown pigments (arrowheads) in the upper layer of dermis (H\&E stain, $100 \times)$.

\section{Patient's perspective}

I will be glad to be of help for future healthcare.

\section{Learning points}

- The aetiology of sarcoidosis is unknown, but tattooing may be a trigger.

- When a granulomatous reaction is observed within a tattoo, systemic sarcoidosis should be kept in mind as a possible diagnosis.

of the skin eruption showed non-caseating epithelioid cell granulomas with black and brown pigments that were localised in the upper layer of dermis (figure 2). Tissue cultures for bacteria, mycobacteria and fungi were negative. Although the patient had been treated with corticosteroid eye drops for uveitis, he subsequently developed bilateral sensorineural hearing loss. At 2 weeks after the systemic administration of oral corticosteroids, the patient's hearing loss, uveitis and skin lesions improved.

The clinical course and the above findings indicated a diagnosis of systemic sarcoidosis, presenting with uveitis, skin eruptions, pulmonary lesions and sensorineural hearing loss. ${ }^{1}$ Facial neuropathy is the most common cranial neuropathy due to sarcoidosis, followed by a hearing deficit. Colover reported that 8 of 118 neurosarcoidosis patients with central nervous system disorder showed deafness. $^{23}$ The aetiology of sarcoidosis is unknown; however, it may be due to an immune reaction to a trigger, such as infection or exposure to chemicals. In the present case, we hypothesise that tattooing triggered the development of sarcoidosis. Sarcoidal skin reactions in a tattoo are rare; however, cases have been reported since $1952 .{ }^{4}$ When clinicians observe a granulomatous reaction within a tattoo, they should be aware of the possibility of systemic sarcoidosis. $^{5}$

Contributors HK researched the topic and wrote the case. YK $\mathrm{HI}$ and MF helped with the research and proofreading of the case report.

Funding The authors have not declared a specific grant for this research from any funding agency in the public, commercial or not-for-profit sectors.

Competing interests None declared.

Patient consent for publication Obtained.

Provenance and peer review Not commissioned; externally peer reviewed.

ORCID iD

Hiroshi Ishii http://orcid.org/0000-0002-2143-5922 
Images in...

\section{REFERENCES}

1 Kluger N. Tattoo-associated uveitis with or without systemic sarcoidosis: a comparative review of the literature. J Eur Acad Dermatol Venereol 2018;32:1852-61.

2 Nowak DA, Widenka DC. Neurosarcoidosis: a review of its intracranial manifestation. J Neurol 2001;248:363-72.
3 Colover J. Sarcoidosis with involvement of the nervous system. Brain 1948;71:451-75.

4 LUBECK G, Epstein E. Complications of tattooing. Calif Med 1952;76:83-5.

5 Lim D, Nantel-Battista M. Sarcoidal reaction in a tattoo. N Eng/ J Med 2020;382:744.

Copyright 2020 BMJ Publishing Group. All rights reserved. For permission to reuse any of this content visit https://www.bmj.com/company/products-services/rights-and-licensing/permissions/

BMJ Case Report Fellows may re-use this article for personal use and teaching without any further permission.

Become a Fellow of BMJ Case Reports today and you can:

- Submit as many cases as you like

- Enjoy fast sympathetic peer review and rapid publication of accepted articles

- Access all the published articles

Re-use any of the published material for personal use and teaching without further permission

Customer Service

If you have any further queries about your subscription, please contact our customer services team on +44 (0) 2071111105 or via email at support@bmj.com. Visit casereports.bmj.com for more articles like this and to become a Fellow 